\title{
MORPHOMETRIC DIGITAL MEASUREMENT OF THE LUMINAL OPENING AREA OF COLONIC CRYPTS (PITS) CAN DIFFERENTIATE THE ADENOMAS FROM OTHER COLONIC LESIONS
}

\author{
Carlos SAUL ${ }^{1}$, João Carlos PROLLA², Vinicius D. da SILVA ${ }^{3}$, Cláudio R. TEIXEIRA ${ }^{4}$ and \\ Artur A. PARADA ${ }^{5}$
}

\begin{abstract}
Context - Differential diagnosis of hyperplastic vs adenomatous lesions is of crucial importance on the daily practice of colonoscopy. Objectives - This study aimed at quantifying digital morphometric characteristics of colonoscopic images obtained with magnification and chromoscopy of three different types of colonic lesions: hyperplastic, adenomas and carcinomas, and the normal mucosa surrounding the lesions. Methods - A total of 2,177 consecutive colonoscopies were analyzed and 105 images were chosen for analysis, divided into 37 hyperplastic lesions, 42 adenomas and 26 carcinomas. Specific digital morphometry was used, to measure the diameter and area of the pits from hyperplastic lesions, adenomatous and carcinomatous lesions, always comparing them with the normal mucosa surrounding pits. Results - Different morphometric measures were performed via image analysis software to measure the mean pit opening diameters and their respective area. The mean pit opening diameters and corresponding area measurements were statistically significant for all groups of lesions examined. Conclusions - The morphometric characteristics of colonoscopy images allowing the observer to compare differences between hyperplastic and adenomatous polyps and colorectal carcinoma lesions. Digital morphometric studies are feasible like the present study shows. This can help the colonoscopist in clinical decisions. A software with morphometric measures can apply and will permit the digital morphometric analysis. The data generated from the application of software, can provide valuable points in differentiation of various lesions, guiding the conduct clinical, already during the endoscopic procedure. Morphometric analysis is more an instance of decision to the colonoscopist and it has important value not for being subjective, but for being objective, since it generates digits of its measures. In these aspects, and among different characteristics, the measure of the area showed to be the most important measure in the differential aspect. Different lesions have different patterns of morphometric measures and theses patterns can be obtained from the study of the characteristics in databases. The endoscopic removal of adenomatous polyps (polypectomy), or a more detailed study of the neoplastic lesions for helping the decision if endoscopic removal (mucosectomy) or surgical resection, and a conservative position in hyperplastic lesions, are proceedings that morphometrics, with another parameters, can help to decide.
\end{abstract}

HEADINGS - Colonic polyps. Colonoscopy. Image processing, computer-assisted.

\section{INTRODUCTION}

It is hard to differentiate between neoplastic and non neoplastic lesions based only in the usual observations of colonoscopy ${ }^{(3,11)}$. Using magnification colonoscopy we are able to observe the colonic pits, that can reflect the histological structure ${ }^{(6)}$ that allow us to predict the histological findings obviating the need of biopsy ${ }^{(20)}$.

KUDO et al. ${ }^{(8)}$, using the endoscopic resource of image magnification, shows the pit pattern, from the morphological and histological point of view ${ }^{(6)}$ established a very used classification. These authors observed, beyond other things, that both adenoma's area and volume are bigger than normal ones ${ }^{(6)}$.
The diagnosis of a lesion must be very precise and for this matter, there are some necessary precision methods and goals to be followed.

Among objective methods, morphometric studies of colonic lesions are being developed, still literature shows that these are being made in a histological level (biopsy specimen or one from lesions taken during colonoscopy $(5,9,14,16,17,21)$.

\section{Objective}

The present study has the objective to develop morphometric methods in endoscopic images of colon lesions in order to measure the area of the colonic pits and to verify if this measure can differ colon lesions.

${ }^{1}$ Universidade Federal de Pelotas, Pelotas, RS.; ${ }^{2}$ Universidade Federal do Rio Grande do Sul, Porto Alegre, RS.; ${ }^{3}$ Pontifícia Universidade Católica do Rio Grande do Sul, Porto Alegre, RS.; ${ }^{4}$ Fundação Riograndense Universitária de Gastroenterologia, Porto Alegre, RS.; ${ }^{5}$ Hospital Nove de Julho, São Paulo, SP, Brasil.

Correspondência: Dr. Carlos Saul - Rua Silva Só, 255 - Bairro Santa Cecília - 90610-270 - Porto Alegre, RS, Brasil. E-mail: csaull@yahoo.com.br 


\section{METHODS}

A total of 2,177 consecutive colonoscopies were analyzed and 714 cases were selected of its magnification images and chromoscopy as well as its histological reports. A new selection of cases was done, based on the quality of the magnification image and its correlation to the diagnosis, which then reduced the number of cases to 128 (images), 105 of which were selected as a definitive study group that was set so the digital morphometric method could be applied (testing set). One should note that all cases were documented before the establishment of the morphometric protocolol and most of dismissed cases did not have normal mucosa at the same distance from the lesion to allow comparison.

The digital morphometric programs we used were the Image 4.5 (Media Cybernetics Silver Spring - USA) and the imaging program (NIH- U.S.A., ScionCorp - U.S.A.). Images with $640 \mathrm{x}$ 480 pixels and 16 million ( 24 bits) tones were used. The digital images were converted to the TIFF (target image file format) format, an uncompressed file that preserves all the information regarding each pixel, different from the jpeg format. Image segmentation and extraction was done by means of program tools, allowing the segmented image section to take on a shape and size appropriate to analyze the lesion. The area and format of the segmentation carried out on the lesion was in all cases strictly the same as the segmentation of the normal mucosa surrounding the lesion.

The morphometric characteristics studied in each one of the lesions were: horizontal and vertical diameters of the pits as well as in the lesions as in the normal area in separated segment of the image program, and images of the same shape and size were analyzed. From each area segment was analyzed both (sick and normal area) width and height were measured up in eight crypts. The selection criteria of these eight crypts were to be as clear as possible in the extracted image area of the exam. The image measure scale used in images was (1 pixel) and registered in sequence.

The parametric test used was the Student $t$ test for pair samples for average rates. In the final analyses, of the data obtained with the morphometric methods described so far, and attempting make these data more consistent, we used a measure of strength of association. The classic measures usually employed, but in the sphere of clinical significance that is not the case in our study, are RR (relative risk) or odds ratio. We used a non-clinical measure which is however applicable to this study format, i.e., the standardized size effect (SE), known in literature as SE. The values of the measure of effect and association strength are:

\section{SE}

\begin{tabular}{cccccccc} 
Effect & Trivial & Short & Moderate & Big & $\begin{array}{c}\text { Much } \\
\text { big }\end{array}$ & $\begin{array}{c}\text { Near of } \\
\text { perfection }\end{array}$ & Perfect \\
Value & 0.0 & 0.2 & 0.6 & 1.0 & 2.0 & 4.0 & Infinity \\
& & \multicolumn{9}{c}{ RESULTS } &
\end{tabular}

One hundred and five cases made up the definitive file submitted to digital morphometric study, divided into three groups:
1) 37 cases of hyperplastic lesions,

2) 42 cases of adenomatous lesions,

3) 26 cases of carcinoma.

The lesion measures have always been compared or referred to normal mucosa close to that lesion to compensate for any difference in magnification or focal distance.

Area and diameter measures were taken from 33 of 37 cases that were part of the hyperplastic group, in 37 of 42 cases of adenomas and in 25 of 26 cases of the carcinoma group, measuring both the horizontal and vertical diameters in an area of 8 pits of extension.

\section{Diameter}

The average diameter of hyperplastic lesions was 1,478216 and in normal ones was 1,457203 and the standard deviation (SD) was 0,542813 on hyperplastic and 0,417441 on normal pits. On adenomas the average diameter was 1,671881 and in normal ones was 1,362325 showing SD of 0,993388 in adenomas and 0,47338 in normal pits. On carcinomas the average diameter was 1,530653 and in normal ones was 1,28179 with SD of 0,862955 in carcinomas and 0,484756 in normal pits.

\section{Area}

Taking the average diameter into consideration the area of the crypts were calculated. The average area of the hyperplastic crypts was 4,277298 and 3,086648 in normal ones $(P<0,001$ Student $t$ test). Adenoma crypts showed an average area of 11,21931 and 3,835781 in normal crypts $(P<0,001$ Student $t$ test) and the area in carcinoma crypts was 6,586791 and 3,674559 in normal ones $(P=0,002$ Student $t$ test $)$.

\section{DISCUSSION}

Hyperplastic polyps or inflammatory polyps are generally not considered pre-cancerous lesions ${ }^{(6)}$. If these lesions are not removed during colonoscopy, procedure time may be reduced, as well as the chances of complications due to polypectomy or mucosectomy, and the procedures may cost less ${ }^{(6)}$. However, there are no safe, objective characteristics that may help distinguish the neoplastic from non-neoplastic lesions satisfactorily. Most endoscopists perform the biopsy or remove the lesion found for histopathological diagnosis.

KUDO et al. ${ }^{(9)}$, examined the correlation between a pit and a gland from the morphological and histopathological standpoint, and established a widely used classification. These authors observed that the area and volume of the adenomatous glands are larger than those of the normal gland ${ }^{(9)}$, an aspect which is also observed in the current study, when morphometric measures are applied to the endoscopic image. Comparing magnified endoscopy and histology, the same author observed a high correlation between diagnoses in the cases of adenomas (82.9\%), slightly less in villous adenomas (73.4\%) and much less in the cases of cancer $(57.7 \%)^{(7)}$.

Other authors ${ }^{(22)}$, employing image magnification associated with chromoscopy and using the Kudo classification ${ }^{(9)}$ obtained final diagnostic accuracy on the order of $80.1 \%{ }^{(22)}$ when differentiating 
neoplastic from non-neoplastic lesions, and concluded that the analysis of the pit pattern in colorectal lesions by image magnification is a useful and objective means of distinguishing neoplastic from non-neoplastic lesions of the colon, but that this technique does not replace histology ${ }^{(22)}$ since if the decision is made by pit analysis, approximately $30 \%$ of the non-neoplastic lesions may be wrongly treated.

Other authors ${ }^{(3,11)}$ had a final accuracy of $82 \%$ (sensitivity $=$ $84.5 \%$ and specificity $=77.7 \%$ ) and $80 \%$ (sensitivity $=69.2 \%$ and specificity $=85.4 \%$ ), respectively.

The highly detailed images of the colon generated by magnification associated with high resolution, may be submitted to an advanced computer program so that the surface morphology of the lesions observed can be analyzed and stored in a data base. Bringing these technologies together will greatly strengthen the diagnostic accuracy of the colonoscopy and diminish the risk of human error ${ }^{(1)}$.

The colorectal mucosa pit opening pattern has been exhaustively studied in recent years, using endoscopy, stereomicroscopy and scanning electron microscopy. The three-dimensional histological image of the surface of individual biopsies was compared to the corresponding pit pattern of the surface images obtained in colonoscopy ${ }^{(21)}$. Another study ${ }^{(10)}$ promoted 3D reconstruction of the colorectal pits using a computerized program (Analyze PC 3.1), which proved an invaluable accessory to view the pit organization. Two studies performed during the endoscopic examination using auto-fluorescence ${ }^{(4)}$ and another using a special spectroscopic measure which was elastic scattering spectroscopy ${ }^{(12)}$ were reported, seeking to achieve a more precise diagnosis during the examination.

In our study we used quantification techniques with digital image analysis in order to evaluate morphological characteristics of colon lesions observed initially under videocolonoscopy with image magnification. The main objectives of quantification are: to increase the objectivity of case evaluation and to use methods that can improve diagnostic, prognostic and possibly therapeutic $c^{(2)}$ capacity. By means of digital morphometry data, this study proposes to evaluate the feasibility of a method to help diagnose colon lesions. We used selected cases, chosen for their definite histopathological diagnosis, with magnified images considered of excellent quality and allowing the programmed measurements.

We utilized a method which has already been employed in studies in other medical fields, trying to detect and document the significance of minimum changes, i.e., the digital morphometric study ${ }^{(15)}$. We aimed at applying morphometric methods to these images by which means we intended to obtain measures to characterize the three types of lesions that were being studied (hyperplastic, adenomatous and carcinomas) morphometrically. In any of the methods used, we performed a direct comparison between the lesion and the surrounding normal mucosa, the latter being the standard of reference for the analysis of each case. The mean pit opening diameters, and the mean area of these openings were statistically significant in all groups of lesions studied, but in the adenoma group the results was more significant $(P<0,001$ Student $t$ test). The measure of strength association (standardized side effect) show a strong association (5.1)

\section{CONCLUSIONS}

The morphometric characteristics of colonoscopy images with chromoscopy and magnification can be studied by digital image analysis, which allows the use of image analysis to assess the number of pit openings in the mucosa per unit of area, the size of the mean diameters of these openings and the pit opening area, allowing the observer to compare differences between hyperplastic and adenomatous polyps and colorectal carcinoma lesions to the surrounding normal mucosa.

The used method was already practiced in other medical areas that eager to detect and document the significance of minimal alterations which is the digital morphometric study. The average diameter of the crypt and the average of the area of this opening crypts had a statistic meaning $(P<0,001)$ in all lesion groups studied and can be used as a differential diagnosis of the lesions.

The digital morphometric analysis can be implemented rapidly, even during the endoscopic procedure. For that, it is necessary the development of a software capable of performing the necessary readings, as demonstrated in this work, but in real time (number of crypts' opening, the opening diameter of them and, from the diameter, the immediate measures of these openings). This morphometric analysis makes concomitantly, and always as comparison, the extent of these data, then obtained from the lesion, and also from the normal mucosa adjacent to it. These generated data, since the software application, can give valuable elements in the differentiation of the various lesions, guiding the clinical conduct, even strengthening the necessity of endoscopic removal of the lesion even during the procedure, for representing an objective parameter that it can associated to another usual parameters of current use in colonoscopy.

With the endoscopic image's definition improvement, through the more powerful magnifications and a higher resolution, as technologies being brought like narrow banding image and the Fuji intelligent color enhancement ${ }^{(13,18,19)}$, the morphometric analysis can be even more detailed and accurate because of the capacity and quality of the image.

The over detailed colon images from magnification source associated to high resolution, can be submitted to a high computer program in a way that the morphology of the observed lesions can be analyzed and stored in a data bank favoring a faster learning and the formation of patterns that can characterize the different lesions and become faster their recognition. These objective characteristics can be tested in defined patterns like standards of each lesion, which will become easier its recognition. From the practical point of view, for instance, the morphometrics measures can strengthen the necessity of endoscopic removal of adenomatous polyps (polypectomy), determinate that a more detailed study of the neoplastic lesion will be made, both elevate or flat lesions, with the propose of endoscopic removal (mucosectomy) or referral to surgery resection, and, at last, stimulate a more conservative conduct in front of the hyperplastic lesions. This kind of technology can increase the colonoscopy diagnosis accuracy and will reduce the risk of human mistakes. 
Saul C, Prolla JC, Silva VD, Teixeira CR, Parada AA. A medida morfométrica digital da área de abertura da luz das criptas colônicas (pits) pode diferenciar os adenomas de outras lesões do cólon. Arq Gastroenterol. 2009;46(2):107-10.

RESUMO - Contexto - O diagnóstico diferencial entre lesões hiperplásicas, adenomatosas e carcinomatosas, é de crucial importância durante a colonoscopia, na tomada de atitude terapêutica. Objetivos - A quantificação de características morfométricas digitais de imagens colonoscópicas obtidas com magnificação e cromoscopia de três diferentes tipos de lesões colônicas: hiperplásicas, adenomatosas e carcinomatosas, como também da mucosa normal adjacente a estas lesões. Métodos - O total de 2.177 colonoscopias consecutivas foram analisadas e 105 imagens colonoscópicas foram selecionadas e escolhidas para análise, divididas em três grupos: 37 lesões hiperplásicas, 42 adenomas e 26 carcinomas. Foram usadas técnicas específicas de morfometria digital para medir o diâmetro e, consequentemente, calcular a área da abertura das glândulas colônicas (pits), das lesões dos três diferentes grupos examinados, comparandose sempre, morfometricamente, com a abertura das glândulas da mucosa normal adjacente à lesão. Resultados - Diferentes medidas morfométricas foram realizadas via software de análise de imagens para medir o diâmetro de abertura das pits e a área das mesmas. O diâmetro das pits e principalmente sua área, em cada uma das lesões examinadas, no comparativo correspondente com sua mucosa normal, demonstrou-se estatisticamente significativo nos três diferentes grupos. Mas a área, nas lesões adenomatosas, foi o valor mais expressivo. Conclusões - As características morfométricas de imagens colonoscópicas permitem ao observador comparar diferenças entre lesões hiperplásicas, adenomatosas e lesões carcinomatosas. Estudos morfométricos digitais são factíveis como o presente estudo demonstrou. Um software com as medidas morfométricas pode ser aplicado e vai permitir análise morfométrica digital. Os dados gerados a partir da aplicação do software, podem fornecer pontos de valor na diferenciação das lesões e auxiliar na condução clínica, até mesmo durante o exame endoscópico. A análise morfométrica é mais uma instância de decisão para o colonoscopista e tem valor muito importante por não ser análise subjetiva e sim objetiva, porque gera dígitos em suas medidas. Neste aspecto, e entre as medidas geradas, os números das medidas morfométricas de área mostrou ser a mais importante e diferencial medida. Lesões diferentes têm diferentes padrões de medidas morfométricas e estes padrões podem ser obtidos a partir de estudos das características das lesões em um banco de dados. A remoção endoscópica de pólipos adenomatosos (polipectomia), um estudo mais detalhado de lesões neoplásicas que oriente sua remoção endoscópica (mucosectomia) ou oriente o encaminhamento para a ressecção cirúrgica e, por fim, uma conduta mais conservadora com lesões hiperplásicas, são procedimentos que a morfometria digital, associada a outros parâmetros, pode auxiliar a decidir.

DESCRITORES - Polipose adenomatosa do cólon. Colonoscopia. Processamento de imagem assistida por computador.

\section{REFERENCES}

1. Axelrad AM, Fleischer DE, Geller AJ, Nguyen CC, Lewis JH, Al-Kawas FH, Avigan MI, Montgomery EA, Benjamin SB. High resolution chromoendoscopy for the diagnosis of diminutive colon polyps: implications for colon cancer screening. Gastroenterology. 1996;10:1253-8.

2. Bartels PH. Quantitation in histopathology: objectives, origins, digital image analysis and unresolved issues. In: Marchevsky AM, Bartels PH, Editors. Image analysis: a primer for pathologists. New York: Raven Press; 1994. p. 1-28.

3. Chapuis PH, Dent OF, Goulston KJ. Clinical accuracy in diagnosis of smal polyps using the flexible fiber optic sigmoidscope. Dis Colon Rectum. 1982;25: 669-72.

4. Dhar A, Johnson K, Pickard D, Novelli MR, Mosse A, Bown S, Bloom SL, Lovat LB. Elastic scattering spectroscopy in the diagnosis of colonic lesions: comparison with clinical and histological diagnosis [abstract]. Endoscopy. 2003;35(suppl II):A1.

5. Kogure E, Kudo S, Tamegai Y, Kashida H, Yamano H, Imai Y. Is it possible to predict histopathological findings by magnifying colonoscopic pit-pattern diagnosis? [abstract] Gut. 2003;52(suppl VI):A9.

6. Kudo S, Hirota S, Nakajima T, Hosobe S, Kusaka H, Kobayashi T, Himori M, Yagyuu A. Colorectal tumors and pit pattern. J Clin Pathol. 1994;47:880-5.

7. Kudo S, Tamura S, Nakajima T, Yamano H, Kusaka H, Watanabe H. Diagnosis of colorectal tumors lesions by magnifying endoscopy. Gastrointest Endosc. 1996;44: 8-14.

8. Kudo S, Kashida H, Tamura T, Kogure E, Imai Y, Yamano H, Hart AR. Colonoscopic diagnosis and management of nonpolypoid early colorectal cancer. World J Surg. 2000;24:1081-90.

9. Kudo S, Rubio CA, Teixeira CR, Kashida H, Kogure E. Pit pattern in colorectal neoplasia: endoscopic magnifying view. Endoscopy. 2001;33:367-73.

10. Mitchell RM, Stobo DE, Arthur K, and Hamilton P. Three dimensional (3D) computerized modeling of colonic crypts [abstract]. Am J Gastroenterol. 2002; 97(9 suppl):370 [S122].

11. Neale AV, Demers RY, Budev H, Scott RO. Physician accuracy in diagnosing colorectal polyps. Dis Colon Rectum. 1987;30:247-50
12. Ogihara T, Namihisa A, Nakaniwa N, Ohkawa A, Kobayashi O, Terai T, Ohkura R, Miwa H, Ohkusa T, Sato N. Colon tumor diagnosis by newly developed auto-fluorescence imaging videoendoscopy [abstract]. Endoscopy. 2003;35(suppl II):A8.

13. Rex D. Colonoscopy and colorectal protection. In: Select topics in GI Oncology Issues in CRC and application of EUS. DDW 2008.

14. Sada M, Mitomi H, Yoshizawa S, Kobayashi K, Igarashi M, Katsumata T, Saigenji K Clinicopathologic and colonoscopic features of serrated adenomas of the colorectum [abstract]. Gut. 2003;52(suppl VI):A7.

15. Silva VD, Prolla JC, Sharma P, Sampliner R, Thompson D, Bartels PH. Karyometry in Barrett's esophagus. Anal Quant Cytol Histol. 2001;23:40-6.

16. Sonwalkar SA, Rembacken BJ. Endoscopic assessment of colonic crypt pattern - Is it good enough to distinguish between the various types of adenomas? Endoscopy. 2003;35(suppl II):A9.

17. Tamegai Y, Kudo S, Fukami N, Kogure E. Pit-pattern and its three dimensional histology of the colorectal tumors [abstract]. Gut. 2003;52(suppl VI):A8.

18. Teixeira C, Canali C, Tonelotto E, Torresini R, Figueiredo L, Pereira-Lima J, Saul C. Endoscopic classification of the fine blood vessel pattern on the surface of colorectal lesions by spectral estimation technology (FICE) accurately predicts the histopathologic diagnosis [abstract]. Gastrointest Endosc. 2007;65:AB352.

19. Teixeira C, Figueiredo L, Torresini R, Tonelotto E, Canali C, Pereira-Lima J, Saul C, FICE (Fuji Intelligent Color Enhancement). Digital chromoendoscopy in the differentiation of neoplastic and non-neoplastic colorectal lesions [abstract]. Gastrointest Endosc. 2007; 65:AB336.

20. Togashi K, Konishi F, Ishizuka T, Sato T, Senba S, Kanazawa K. Efficacy of magnifying endoscopy in the differential diagnosis of neoplastic and non-neoplastic polyps of the large bowel. Dis Colon Rectum. 1999;42:1602-8.

21. Tomenius H. Three-dimensional interpretation of the colorectal pit patterns (types to V of Kudo). In: Jaramillo E, Hultcantz R, Rubio CA, Slezak P, editors. Interactive atlas of gastrointestinal endoscopy. Stockholm: Karolinska University Press; 2001. p.1680-8.

22. Tung SY, Wu CS, Su MY. Magnifying colonoscopy in differentiating neoplastic from nonneoplastic colorectal lesions. Am J Gastroenterol. 2001;96:2628-32.

Recebido em 19/5/2008. Aprovado em 15/9/2008 